\title{
Synthesis and Physicochemical Properties of Ionic Liquids: 1-Alkenyl-2,3-dimethylimidazolium Tetrafluoroborates
}

\author{
Gwan-Hong Min, Taeeun Yim, Hyun Yeong Lee, Hyo-Jin Kim, Junyoung Mun, \\ Sangmi Kim, Seung M. Oh, and Young Gyu Kim \\ Department of Chemical and Biological Engineering, Research Center for Energy Comersion \& Storage,

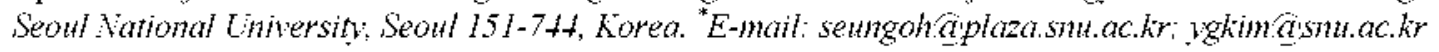 \\ Received Mav $\mathrm{H}_{1} 2007$
}

\begin{abstract}
1-Alkenỵl-2.3-dimethylimidazolium tetraflıoroborate ionic liquids having an olefinic substituent were synthesized and characterized. Among them. [AMMIm]BF 4 with an allyl group showed lower viscosity. higher ionic conductivity, and a wider electrochemical window compared with its analogue having a saturated alkyl substituent. An EDLC with $\left[\mathrm{AMMIm}_{\mathrm{B}} \mathrm{B}_{4}\right.$ showed better performance than that with [PMMIm]BF 4 , too.
\end{abstract}

Key Words : Ionic liquids, 1-Alkenyl-2,3-dimethylimidazolium tetrafluoroborates, Olefinic substituent. Physicochemical properties. Electrochemical window:

\section{Introduction}

Ionic liquids (ILs) are salts that are liquid at a wide temperature range. ILs have received great interest recently due to their unique properties-wide liquid range good conductivity: wide electrochemical windows. non-volatility. and non-flammability. ${ }^{-4}$ Therefore they have been studied by many researchers as a promising alternative to the conventional organic solvents ${ }^{\text {l. }}$ or organic electrolytes. ${ }^{3.4}$ The widely used cations are imidazoliums and cyclic or acyclic quaternary ammoniums. and the anions are tetrafluoroborate. hexafluorophosphate and bis(trifluoromethanesulfonyl)imide (TFSI). Among these, the ionic liquids containing an imidazolium cation have the potential to be used as electrolytes because of their high conductivity and low viscosity. ${ }^{4}$

Several studies have attempted to control the physicochemical properties of ILs through the novel design of their cations and anions for practical use. One of the problems encountered with the imidazolium-based ILs is the lack of electrochemical stability. It is known that the anodic stability of the ionic liquids is governed by the anionic species. However. we have found that an appropriate substituent on the cation could affect the anodic stability of ILs. That is. the introduction of an olefinic substituent into the 1.3disubstituted imidazolium tetrafluoroborates resulted in the enhancement of the anodic stability as well as the decrease of riscosity and the increase of ionic conductivity. However the ILs bearing the allylic substituent on the imidazolium nitrogen atom still have some problems in an electrochemical application such as Li batteries. The most serious problem is that the imidazolium cation decomposes at about $1 \mathrm{~V}$ (vs. $\mathrm{Li} / \mathrm{Li}^{+}$) mainly due to the presence of an acidic proton at the $\mathrm{C}-2$ position. ${ }^{4.6}$ This urges to reconsider a novel design of the imidazolium-based ILs as an electrolyte or altemative negative electrode material for the practical application of the imidazolium-based ILs to $\mathrm{Li}$ batteries.
One of the simplest ways to remove the acidic proton from the imidazolium ring is to substitute the acidic proton with an alkyl group at the C-2 position. ${ }^{7}$ It was reported that 1.2.3-trialkyl substituted imidazolium salts showed an increased cathodic stability and thermal stability. However. their viscosities and the melting points were also increased as a result of the introduction of an alkyl group at the C-2 position of the inidazolium ring. Therefore. we wanted to extend our previous results to the 2-alkyl substituted imidazolium derivatives. It was expected that the introduction of an olefinic substituent would reduce some problems of the 2-alkylimidazolium-based ILs such as the high viscosity and low ionic conductivity. while maintaining the enhanced cathodic stability: Moreover, the anodic stability of the 2-alky limidazolium-based ILs could be improved due to the olefinic substituent as was the case in our previous work.

As part of an ongoing sistematic work to enhance the electrochemical stability of imidazolium-based ILs, we have prepared three new inidazolium tetrafluoroborates with a methyl group at the $\mathrm{C}-2$ position and an olefinic substituent on the nitrogen atom of the imidazolium ring. Herein we wish to report their physical and electrochemical properties as follows

\section{Experimental Section}

${ }^{l} \mathrm{H}$ and ${ }^{13} \mathrm{C}$. NMR spectra were obtained using $\mathrm{CDCl}_{2}$ as solvent on a JEOL JNM LA-300 spectrometer $(300 \mathrm{MHz}$ for ${ }^{\mathrm{l}} \mathrm{H}$ NMR and $75 \mathrm{MHz}$ for ${ }^{13} \mathrm{C}$. NMR). The ${ }^{\mathrm{l}} \mathrm{H}$ NMR data were reported as follows in ppm $(\delta)$ from the internal standard (TMS, $0.0 \mathrm{ppm}$ ). chemical shift (multiplicity: coupling constant in $\mathrm{Hz}$. integration), and the ${ }^{13} \mathrm{C}$ NMR data in ppm $(\delta)$ from the internal standard (TMS $0.0 \mathrm{ppm}$ ).

Sodium contents were measured by ICP-AES using a Shimadzu ICPS-1000IV spectrometer. Water contents were determined by Karl-Fischer coulometry using a Mettler Toledo DL39 coulometric titrator. 
Thermal properties were analyzed by DSC and TGA. Crystallization point and melting point were determined by using TA Instruments Differential Scanning Calorimeter (DSC) Q1000 under $\mathrm{N}_{2}$ atmosphere. Thermograms were recorded during heating from $-800^{\circ} \mathrm{C}$ to $100^{\circ} \mathrm{C}$ scans at a heating rate of $10^{\circ} \mathrm{C} \mathrm{min}{ }^{\prime}$ after cooling to $-80^{\circ} \mathrm{C}$ scans at a cooling rate of $10^{\circ} \mathrm{C} \mathrm{min} !$. Thermal decomposition temperature was recorded by using TA Instruments SDT Q600 under $\mathrm{Ar}$ atmosphere. Heating rate and terminal temperature were set at $10^{\circ} \mathrm{C}$ min ' and $800^{\circ} \mathrm{C}$, respectively.

Density was measured by weighing a measured volume of the ILs. Viscosity measurements were carried out on a Brookfield DV-II+ coneplate viscometer.

lonic conductivity was determined by the complex impedance measurements with platinum electrodes, using a CHI660A electrochemical workstation in the frequency range from I Hz to $100 \mathrm{kHz}$. The cell constant of the cell was $1.6 \mathrm{~cm}$ ', determined with a $1.0 \mathrm{M} \mathrm{KCl}$ aqueous solution. Linear sweep voltammetry was performed with a CHI660A electrochemical workstation for the electrochemical stability window measurement at a scan rate of 10 $\mathrm{mV} \mathrm{s}{ }^{1}$ by using a platinum electrode $\left(1.96 \times 10^{3} \mathrm{~cm}^{2}\right)$ as a working electrode. The working electrode was polished before every measurement. Platinum foil was used as a counter electrode and silver wire as a quasi-reference electrode. In this work, the cathodic and anodic limits were arbitrarily defined as the potential at which the current density reached $1 \mathrm{~mA} \mathrm{~cm}{ }^{2}$. All the electrochemical measurements were performed at room temperature unless otherwise specified.

To make the electrodes of an EDLC (electric double-layer capacitor), BP-20 (activated carbon from Kuraray Chemical of which surface area is $2000 \mathrm{~m}^{2} \mathrm{~g}^{1}$ ) was mixed with acetylene black and poly(vinylidene fluoride) (80:10:10 wt. $\%$ ) and the resulting mixed slurry was coated on an $\mathrm{Al}$ current collector and pressed. The 2032 coin cells were assembled with symmetric electrodes and ILs. They were charged and discharged by constant current between $2 \mathrm{~V}$ and $0 \mathrm{~V}$. The specific capacitance, $\mathrm{C}$, was calculated by $\mathrm{Q}=\mathrm{CV}$ ( $V$ is voltage and $\mathrm{Q}$ was measured from multiplying discharge constant current by discharge time).

Preparation of the ionic liquids. 2-Methyl substituted imidazolium tetrafluoroborates with an olefinic substituent were prepared according to the same procedure described in our previous report, ${ }^{5}$ which is a modified procedure based on the work done by Wilkes and Zaworotko (Scheme 1). ${ }^{8}$ The corresponding 2-methylimidazolium tetrafluoroborates with

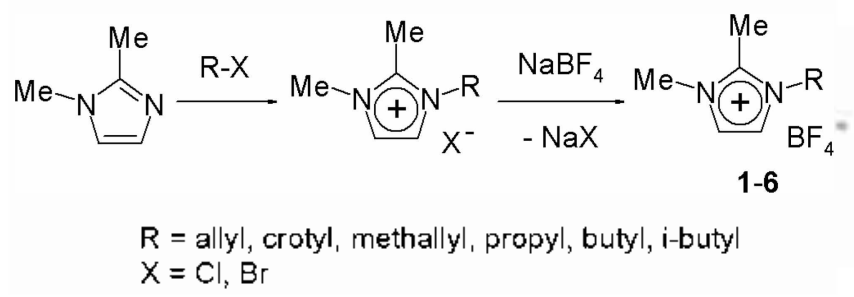

Scheme 1. Preparation of 2-methylimidazolium tetralluoroborates.
Table 1. Maximum content of sodium and water in the ILs prepared

\begin{tabular}{|c|c|c|c|c|}
\hline No. & lonic liquids & $\mathrm{R}$ & $\begin{array}{c}\mathrm{Va} \\
(\mathrm{pp})\end{array}$ & $\begin{array}{c}\mathrm{H}_{2} \mathrm{O} \\
(\mathrm{ppm})\end{array}$ \\
\hline 1 & |AMMlm|BF. & Allyl & 133 & 300 \\
\hline 2 & {$\left[\mathrm{CMMIm} \mid \mathrm{B} \mathrm{F}_{\mathrm{s}}\right.$} & Croty] & 118 & 312 \\
\hline 3 & |MaMMIm|BF ${ }_{1}$ & Msthally] & 147 & 305 \\
\hline 4 & {$[\mathrm{PMMlm}] \mathrm{BF}_{+}$} & Propyl & 130 & 302 \\
\hline 5 & {$[\mathrm{BMMlm}] \mathrm{BF}_{+}$} & Butyl & 131 & 307 \\
\hline 6 & [iBMMlm]BF ${ }_{\downarrow}$ & Isobutyl & 131 & 315 \\
\hline
\end{tabular}

saturated alkyl substituents were also made for comparison following the same synthetic protocol.

General procedure for the preparation of the imidazolium halides. To a stirred solution of freshly distilled 1,2dimethylimidazole $(9.61 \mathrm{~g} .100 \mathrm{mmol})$ in acetonitrile (70 $\mathrm{nL}$ ) was added requisite alkyl halide (R-X, $110 \mathrm{mmol})$ dropwise at $0^{\circ} \mathrm{C}$. The reaction mixture was stirred for $24-48$ $h$ at $30^{\circ} \mathrm{C}$. Removal of the solvent under reduced pressure afforded crude 1-R-2.3-dimethylimidazolium halide. Completion of the quaternization reaction was confirmed by ${ }^{\prime} \mathrm{H}$ and ${ }^{13} \mathrm{C}$ NMR spectra. The crude product was used without further purification for the next step, an anion metathesis.

General procedure for the anion metathesis. Io a solution of the crude imidazolium halide, obtained from the above reaction, in acetone $(70 \mathrm{~mL})$ was added sodium tetrafluoroborate $(10.90$ g. $100.0 \mathrm{mmol})$. The reaction mixture was stirred for $24 \mathrm{~h}$ at room temperature. The resulting mixture was filtered through a pad of neutral aluminum oxide to remove the sodium salt and color. Evaporation of the solvent under reduced pressure afforded the corresponding imidazolium tetrafluoroborate.

Completion of the anion-exchange reactions was confirmed by ${ }^{1} \mathrm{H}$ and ${ }^{1} \mathrm{C}$ NMR specta. The $\mathrm{Na}$ content of all the imidazolium tetrafluoroborates prepared in the present study was less than $150 \mathrm{ppm}$ by $\mathrm{JCl}-\mathrm{AES}$ and their water content was below $320 \mathrm{ppm}$ by Karl-Fischer titration (Jable I).

1-Allyl-2,3-dimethylimidazolium tetrafluoroborate (|AMMIm|BF 4 ) (1). [AMMIm]Br: ${ }^{1} \mathrm{H}$ NMR $\delta 2.80$ (s, $\left.3 \mathrm{H}\right)$, $4.00(\mathrm{~s}, 3 \mathrm{H}), 4.93(\mathrm{~d}, J=5.7,2 \mathrm{H}), 5.28(\mathrm{~d}, J=17.0, \mathrm{IH})$. $5.39(\mathrm{~d}, J=10.3,1 \mathrm{H}), 5.90-6.02(\mathrm{~m}, \mathrm{IH}), 7.53(\mathrm{~d}, J=2.0$, $1 \mathrm{H}), 7.70(\mathrm{~d}, J=2.0,1 \mathrm{H}) ;{ }^{13} \mathrm{C}$ NMR $\delta 9.0,34.1,48.8,118.4$, $119.6,120.9,128.4,142.2$.

[AMMLm]B $F_{4}$ : Yield $86 \% ; T_{\mathrm{c}}-62{ }^{\circ} \mathrm{C} ; T_{\mathrm{d}} 381{ }^{\circ} \mathrm{C}$; 'H NMR $\delta 2.62(\mathrm{~s}, 3 \mathrm{H}), 3.84(\mathrm{~s}, 3 \mathrm{H}), 4.72(\mathrm{~d}, J=5.9 .2 \mathrm{H}), 5.28(\mathrm{~d}, J=$ $17.0, \mathrm{lH}), 5.43(\mathrm{~d}, J=10.4,1 \mathrm{H}), 5.88-5.99(\mathrm{~m}, 1 \mathrm{H}) .7 .19(\mathrm{~d}$, $J=2.0, \mathrm{lH}), 7.28(\mathrm{~d}, J=2.0,1 \mathrm{H}){ }^{1 .} \mathrm{C} \mathrm{C}$ NMR $\delta 9.0,34.9$, $50.3,120.0,121.1,122.5,130.4,144.5$.

1-Crotyl-2,3-dimethylimidazolium tetrafluoroborate (|CMMIm|BF 4 ) (2). [CMM]m]Cl: 'H NMK $\delta 1.76$ (d. $J=$ $6.4,3 \mathrm{H}), 2.82(\mathrm{~s}, 3 \mathrm{H}), 4.04(\mathrm{~s}, 3 \mathrm{H}), 4.83(\mathrm{~d}, J=6.4,2 \mathrm{H})$, $5.52-5.63(\mathrm{~m}, 1 \mathrm{H}), 5.83-5.95(\mathrm{~m}, 1 \mathrm{H}), 7.38(\mathrm{~d}, J=2.0, \mathrm{lH})$, $7.62(\mathrm{~d}, J=2.0,1 \mathrm{H}) ;{ }^{1 .} \mathrm{C}$ NMR $\delta 9.5,17.7,35.1,50.3,120.1$. 
$122.4,122.5,133.7,144.0$

[CMMIm] BF $:$ Yield $85 \% ; T_{\mathrm{c}}-65^{\circ} \mathrm{C}: T_{\mathrm{m}}-56^{\circ} \mathrm{C}: T_{\mathrm{d}} 254$ ${ }^{\circ} \mathrm{C} ;{ }^{1} \mathrm{H}$ NMR $\delta 1.75(\mathrm{~d}, J=6.6,3 \mathrm{H}), 2.60(\mathrm{~s}, 3 \mathrm{H}), 3.80(\mathrm{~s}$, $3 \mathrm{H}), 4.62(\mathrm{~d}, J=6.4,2 \mathrm{H}), 5.50-5.60(\mathrm{~m}, 1 \mathrm{H}), 5.79-5.90(\mathrm{~m}$, lH). $7.20(\mathrm{~d}, J=2.0,1 \mathrm{H}) .7 .29(\mathrm{~d}, J=2.0,1 \mathrm{H}) ;{ }^{1.3} \mathrm{C}$ NMR $\delta$ $9.2,17.7,34.9,50.1,120.8,122.4,122.8 .133 .2,144.1$.

1,2-Dimethyl-3-methallylimidazolium tetrafluoroborate ([MaMMIm|BF $\mathbf{B})(3)$. [MaMMIm] Cl; ' $\mathrm{H}$ NMR $\delta 1.78$ $(\mathrm{s}, 3 \mathrm{H}), 2.76(\mathrm{~s}, 3 \mathrm{H}), 4.05(\mathrm{~s}, 3 \mathrm{H}), 4.73(\mathrm{~s}, \mathrm{IH}), 4.87(\mathrm{~s}, 2 \mathrm{H})$, $5.05(\mathrm{~s}, \mathrm{lH}) .7 .49(\mathrm{~d}, J=2.0, \mathrm{lH}), 7.76(\mathrm{~d}, J=2.0,1 \mathrm{H}) ;{ }^{13} \mathrm{C}$ NMR $\delta 10.6,20.0,36.0,54.4,115.1,121.9,123.1,137.8$. 144.5 .

[MaMMIm]BF: Yield 77\%; $T_{\mathrm{m}} 57^{\circ} \mathrm{C} ; T_{\mathrm{d}} 358{ }^{\circ} \mathrm{C} ;{ }^{\mathrm{H}} \mathrm{H}$ NMR $\delta 1.76(\mathrm{~s}, 3 \mathrm{H}), 2.59(\mathrm{~s}, 3 \mathrm{H}), 3.85(\mathrm{~s}, 3 \mathrm{H}), 4.63(\mathrm{~s}, 2 \mathrm{H})$, $4.71(\mathrm{~s}, 1 \mathrm{H}), 5.07(\mathrm{~s}, \mathrm{lH}), 7.20(\mathrm{~d}, J=2.2, \mathrm{IH}), 7.34(\mathrm{~d}, J=$ $2.2,1 \mathrm{H}) ;{ }^{13} \mathrm{C}$ NMR $\delta 9.5,19.7,35.3,54.0,115.2,121.4$, 122.6. 137.7, 144.7.

1,2-Dimethyl-3-propylimidazolium tetrafluoroborate ([PMMIm|BF + ) (4). [PMMIm]Br; 'H NMR $\delta 1.02$ (t. $J=$ $7.4,3 \mathrm{H}), 1.84-1.96(\mathrm{~m}, 2 \mathrm{H}), 2.83$ (s, 3H), 4.03 (s, 3H), 4.18 $(\mathrm{t} . J=7.4,2 \mathrm{H}), 7.46(\mathrm{~d}, J=1.8, \mathrm{lH}) 7.66(\mathrm{~d}, J=1.8, \mathrm{lH})$; ${ }^{13} \mathrm{C}$ NMR $\delta 10.5,10.6,23.1,35.7,50.1,121.3,122.9,143.9$.

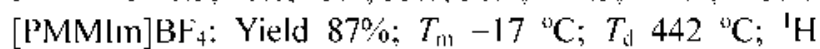
NMR $\delta 0.99(\mathrm{t}, J=7.3,3 \mathrm{H}), 1.79-1.91(\mathrm{~m}, 2 \mathrm{H}), 2.54(\mathrm{~s}, 3 \mathrm{H})$, $3.82(\mathrm{~s}, 3 \mathrm{H}), 4.04(\mathrm{t}, J=7.3,2 \mathrm{H}), 7.23(\mathrm{~d}, J=2.0,1 \mathrm{H}), 7.30$ $(\mathrm{d}, J=2.0, \mathrm{lH}) ;{ }^{13} \mathrm{C}$ NMR $\delta 9.0,10.5,23.0,34.8,49.7$. 121.0. 122.4, 144.0.

1-Butyl-2,3-dimethylimidazolium tetrafluoroborate ([BMMIm]BF $)$ (5). [BMMIm]Br: 'H NMR $\delta 0.97(\mathrm{t}, J=$ 7.3, 3H), 1.34-1.47 (m, 2H), 1.77-I.85(m, 2H), $2.83(\mathrm{~s}, 3 \mathrm{H})$, $4.04(\mathrm{~s}, 3 \mathrm{H}), 4.22(\mathrm{t}, J=7.5,2 \mathrm{H}) .7 .46(\mathrm{~d}, J=2.1,1 \mathrm{H}), 7.7 \mathrm{l}$ $(\mathrm{d}, J=2.1, \mathrm{lH}) ;{ }^{13} \mathrm{C}$ NMR $\delta 11.1,13.6,19.6 .31 .8,36.3$. $48.8,121.1,123.1,143.8$.

[BMM]m]BF 4 : Yield 86\%; $T_{\mathrm{c}}-29^{\circ} \mathrm{C} ; T_{\mathrm{m}} 21^{\circ} \mathrm{C} ; T_{\mathrm{d}} 401$ ${ }^{\circ} \mathrm{C} ;{ }^{1} \mathrm{H}$ NMR $\delta 0.96(\mathrm{t}, J=7.3,3 \mathrm{H}), 1.31-1.43(\mathrm{~m}, 2 \mathrm{H}) .1 .72-$ $\mathrm{l} .82(\mathrm{~m}, 2 \mathrm{H}), 2.6 \mathrm{l}(\mathrm{s}, 3 \mathrm{H}), 3.81(\mathrm{~s}, 3 \mathrm{H}), 4.06(\mathrm{t}, J=7.5 .2 \mathrm{H})$, $7.23(\mathrm{~d}, J=2.0, \mathrm{lH}) .7 .30(\mathrm{~d}, J=2.0,1 \mathrm{H}){ }^{13} \mathrm{C}$ NMR $\delta 9.5$. $13.5,19.5,31.6,35.2,48.4,120.8,122.6,143.9$.

1,2-Dimethyl-3-isobutylimidazolium tetrafluoroborate (|iBMMIm|BF $)$ (6). [iBMMIm]Br: 'H NMR $\delta$ l.0l (d, $J=$ $6.6,6 \mathrm{H}), 2.08-2.2 \mathrm{I}(\mathrm{m}, \mathrm{lH}), 2.82(\mathrm{~s}, 3 \mathrm{H}), 4.01(\mathrm{~d}, J=7.5$, $2 \mathrm{H}), 4.05(\mathrm{~s}, 3 \mathrm{H}), 7.31(\mathrm{~d}, J=2.0,1 \mathrm{H}) .7 .59(\mathrm{~d}, J=2.0,1 \mathrm{H})$; ${ }^{13} \mathrm{C}$ NMR $\delta 11.3,19.8,29.4,36.4,56.0,121.6,123.0,144.2$.
[iBMMlm]BF; Yield $85 \% ; T_{11} 63^{\circ} \mathrm{C} ; T_{\mathrm{s}}-50{ }^{\circ} \mathrm{C} ; T_{\mathrm{d}} 394$ ${ }^{\circ} \mathrm{C}:{ }^{1} \mathrm{H}$ NMR $\delta 0.96(\mathrm{~d}, J=6.6,6 \mathrm{H}), 2.02-2.15(\mathrm{~m}, 1 \mathrm{H}), 2.61$ $(\mathrm{s}, 3 \mathrm{H}), 3.83(\mathrm{~s}, 3 \mathrm{H}), 3.89(\mathrm{~d}, J=7.5,2 \mathrm{H}), 7.16(\mathrm{~d}, J=2.2$. IH), $7.29\left(\mathrm{~d}, J=2.2\right.$, IH); ${ }^{1} \mathrm{C}$ NMR $\delta 9.9,19.6,29.2,35.4$, $55.7,121.3,122.5,144.3$.

\section{Results and Discussion}

Thermal behaviors. Jable 2 lists the crystallization point (T), melting point $\left(T_{m}\right)$, and decomposition temperature $\left(T_{\mathrm{l}}\right)$ of the ILs prepared in this work. The DSC chaits of [AMM $\left.]_{m}\right] \mathrm{BF}_{4}$ and $\left[\mathrm{CMM} \mathrm{I}_{\mathrm{m}} \mathrm{BF}_{4}\right.$ are shown in Figure 1. The 2-methylimidazolium salts with an allyl (1) or crotyl group (2) were liquid at room temperature (entries I and 2), while the IL having a methallyl group was white solid (entry 3). Decomposition temperature of the ILs with an olefinic substituent were beyond $350{ }^{\circ} \mathrm{C}$ except for [CMMIm] $\mathrm{BF}{ }_{4}$ but lower than that of the IIs with saturated alkyl substituents. This observation that an introduction of the olefinic substituent to the imidazolium ring lowers the

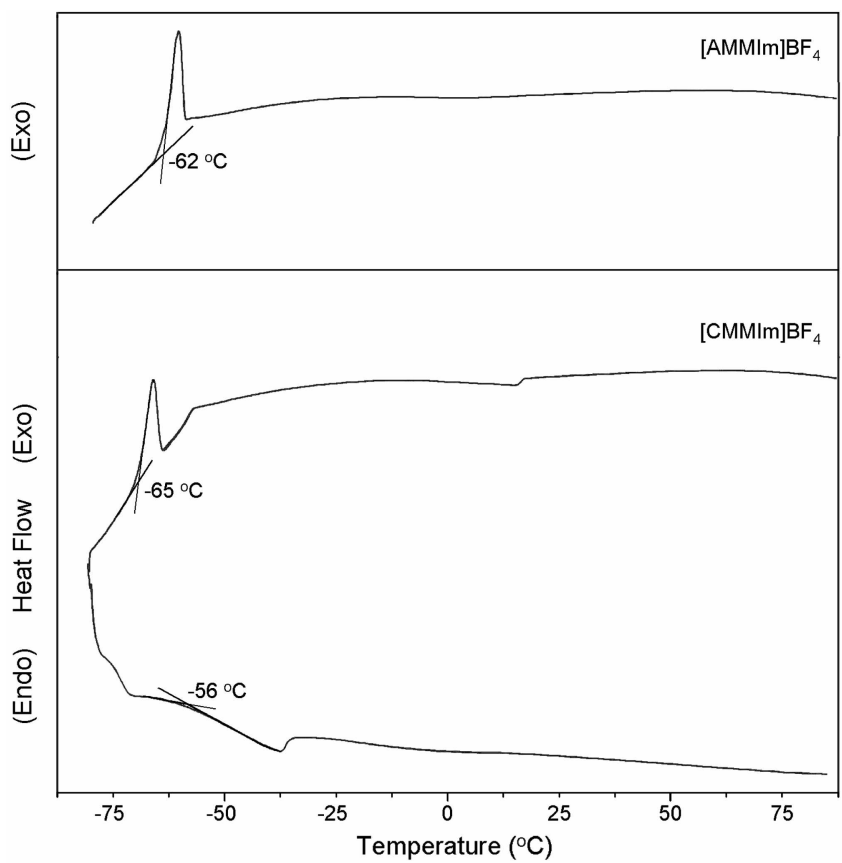

Figure 1. 'I he ISSC charts of the II s with an olelinic substituent.

Table 2. 'I he structures and physicochenical properties of the II s prepared

\begin{tabular}{|c|c|c|c|c|c|c|c|c|}
\hline No. & Ionic liquids & $\mathrm{R}$ & $\begin{array}{c}T_{c} \\
\left({ }^{\prime \prime} \mathrm{C}\right)\end{array}$ & $\begin{array}{l}7_{\mathrm{m}} \\
\left({ }^{\circ} \mathrm{C}\right)\end{array}$ & $\begin{array}{c}T_{\mathrm{d}} \\
\left({ }^{\prime \prime} \mathrm{C}\right)\end{array}$ & $\begin{array}{c}\mathrm{d} \\
\left(\mathrm{gL}^{-1}\right)\end{array}$ & $\begin{array}{c}\eta \\
(\mathrm{cP})\end{array}$ & $\begin{array}{c}\sigma \\
\left.(\mathrm{mS} \mathrm{cm})^{-1}\right)\end{array}$ \\
\hline 1 & {$[\mathrm{AMMIm}] \mathrm{BF}_{4}$} & Allyl & -62 & $N^{4}$ & 381 & 1.16 & 199 & 3.2 \\
\hline 2 & [CMMIm]BFa & Crotyl & -65 & -56 & 254 & 1.15 & 257 & 1.7 \\
\hline 3 & [MaMMIm] $\mathrm{BF}_{a}$ & Mcthallyl & ND & 57 & 358 & $-^{k}$ & $-{ }^{k}$ & $5.3^{\circ}$ \\
\hline 4 & [l'MMIm] & l'ropyl & NI) & -17 & 442 & 1.13 & 330 & 1.7 \\
\hline 5 & [3MMIm] & Butyl & -29 & 21 & 401 & 1.03 & 372 & 0.7 \\
\hline 6 & [il3MMlm]lisF+ & Isobutyl & -50 & 63 & 394 & $-^{k}$ & $--^{b}$ & $10.9^{d}$ \\
\hline
\end{tabular}

"ND); not detected. "Solid. "Measured at $70^{\circ} \mathrm{C}$, "Measured at $100^{\circ} \mathrm{C}$. 
decomposition temperature agrees with our previous results. ${ }^{5}$ However, all of them are more stable than conventional organic carbonate electrolytes.

Physical properties. Table 2 also shows density (d). viscosity $(\eta)$ and ionic conductivity $(\sigma)$ of the II.s prepared. As expected, the II s with the olefinic substituent showed lower viscosity and higher ionic conductivity than their analogues having the saturated alkyl substituents. [AMMIm] BF ${ }_{4}$ shows $199 \mathrm{cP}$ of viscosity and $3.2 \mathrm{mS} \mathrm{cm}{ }^{1}$ of ionic conductivity, which are contrasted by the higher viscosity $(330 \mathrm{cP})$ and lower ionic conductivity $(1.7 \mathrm{mS}$ $\mathrm{cm}^{\prime}$ ) of its saturated alkyl analogue [PMM]m] $\mathrm{BF}_{4}$. The lower viscosity and higher ionic conductivity of the imidazolium salts with the olefinic substituent would be due to their relatively planar structure of an allyl group. A more planar structure would allow relatively facile slip between molecules, resulting in lower viscosity." In this work, the relatively planar allyl or crotyl group can take a more or less parallel position to the planar imidazolium ring, which seems to hold the planarity of the whole cation itself compared to that having the saturated alkyl substituents.

Electrochemical behavior. The electrochemical stability windows of the ILs determined from their linear sweep voltammograms are listed in lable 3 and a linear sweep voltammogram of $[\mathrm{AMMIm}] \mathrm{BF}$; is shown together with those of 1-allyl-3-methylimidazolium tetrafluoroborate $\left([\mathrm{AMlm}] \mathrm{BF}_{4}\right)$ and $\left[\mathrm{PMMIm}_{\mathrm{B}} \mathrm{F}_{4}\right.$ in Figure 2. The cathodic limits of the ILs with the olefinic substituent are similar to those of their analogues with saturated alkyl substituents. In particular, the cathodic stability of [AMMlm] $\mathrm{BF}_{4}$ was better

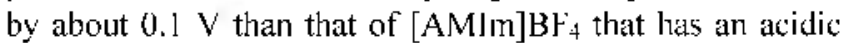

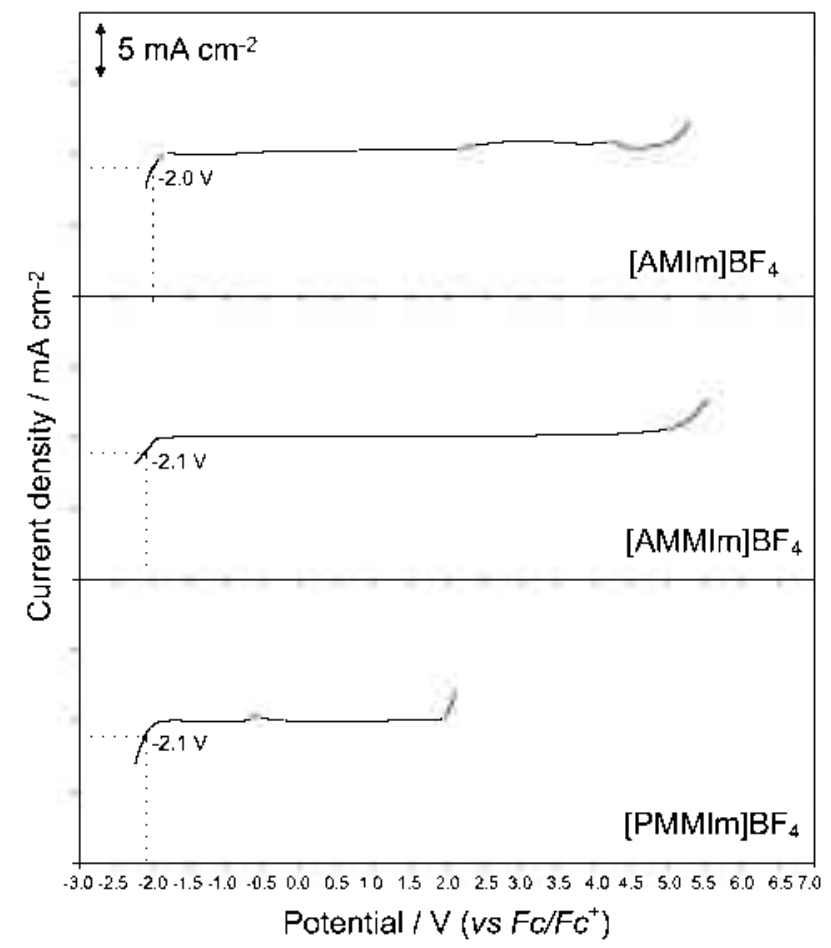

Figure 2. I inear sweep voltammograms of the II s prepared wilh a platinum working clectrode.
Table 3. The electrochemical windows of the lLs prepared

\begin{tabular}{|c|c|c|c|c|}
\hline \multirow{2}{*}{ No. } & \multirow{2}{*}{ Ionic liquids } & \multicolumn{2}{|c|}{ Voltage limit" (V) } & \multirow{2}{*}{$\begin{array}{l}\text { Filectrochemical } \\
\text { window (v) }\end{array}$} \\
\hline & & Cathode & Anode & \\
\hline 1 & $|\wedge M M I m| B F_{t}$ & -2.1 & 5.3 & 7.4 \\
\hline 2 & $|\mathrm{CM}| \mathrm{M}|\mathrm{m}| \mathrm{BF}$ & -2.1 & 2.3 & 4.4 \\
\hline 4 & [PMMIm]BF & -2.1 & 2.2 & 4.3 \\
\hline 5 & [BMMIIm]BF_ & -2.1 & 2.0 & 4.1 \\
\hline 7 & {$\left[\mathrm{AMIm}_{\mathrm{m}}\right] \mathrm{BF}_{4}$} & -2.0 & 5.1 & 7.1 \\
\hline
\end{tabular}

"Potential ws $F_{C} F_{C}$ (Pt working electrode).

proton at the $\mathrm{C}-2$ position (Figure 2, Table 3 ), It is interesting to note that $[\mathrm{AMMLn}] \mathrm{B} F_{4}$ shows much enhanced anodic stability by about $3.0 \mathrm{~V}$, while the anodic stability of [CMM]m]BF, is similar to those of [PMMlm]BF $F_{4}$ and $[\mathrm{BMMlm}] \mathrm{BF}_{4}$. The anodic limit of [AMMlm]BF $\mathrm{A}_{4}$ was assigned as $5.3 \mathrm{~V} v \mathrm{~s}, F \mathrm{C} / \mathrm{Fc}$, resulting in the widest electrochemical window of $7.4 \mathrm{~V}$. This value is even greater than that of $[\mathrm{AM}[\mathrm{m}] \mathrm{BF}$, that showed the electrochernical window of 7.1 ( Jable 3).

At this stage, it was confirmed whether the enhanced electrochemical stability could be obtained under other conditions. 'Thus, there arose a need for the linear sweep voltammetry by using the other working electrode. Figure 3 shows the linear sweep voltammogram of [AMMIm]BF by using a glassy carbon as a working electrode and a silver wire as a reference electrode. Here, ferrocene was used as an internal reference. An interesting result was obtained under these conditions. [AMMIm] BF ${ }_{+}$exhibited a cathodic limit of $-2.9 \mathrm{~V}$ and an anodic limit of $6.3 \mathrm{~V}(v S . F \mathrm{C} / F \mathrm{c})$, resulting in an even wider electrochemical window of $9.2 \mathrm{~V}$ than that measured with the $\mathrm{Pt}$ electrode. This indicates that the enhanced electrochemical stability could be achieved in other electrochemical systems as well, indicating a possibility of application to various electrochemical conditions. Moreover, these observations, along with our previous results, confirm that a simple functionalization on the imidazolium ring can lead to the enhancement of the anodic and/or cathodic stability in linear sweep voltammetry. ${ }^{5.10}$

Applcation to an electric double-layer capacitor (EDLC). [AMMLm]BF ${ }_{+}$and [PMMLm]B ${ }_{4}$ were examined as an electrolyte of an EDLC for a practical application. The

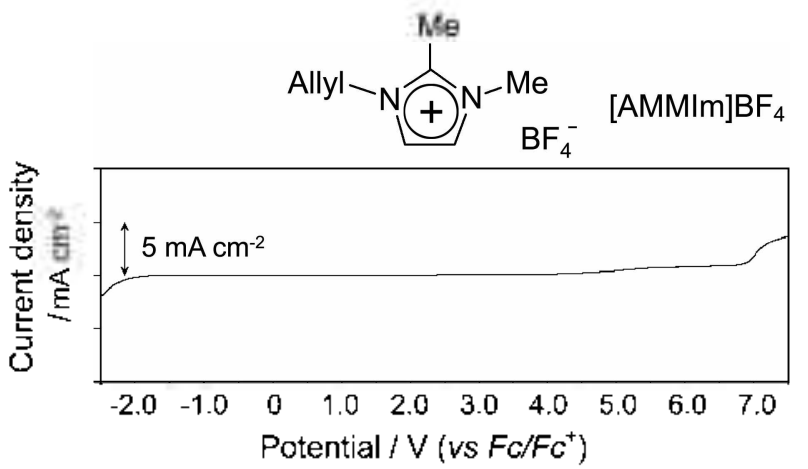

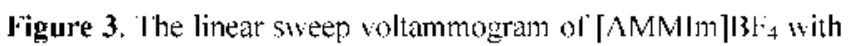
a glassy carbon working electrode. 


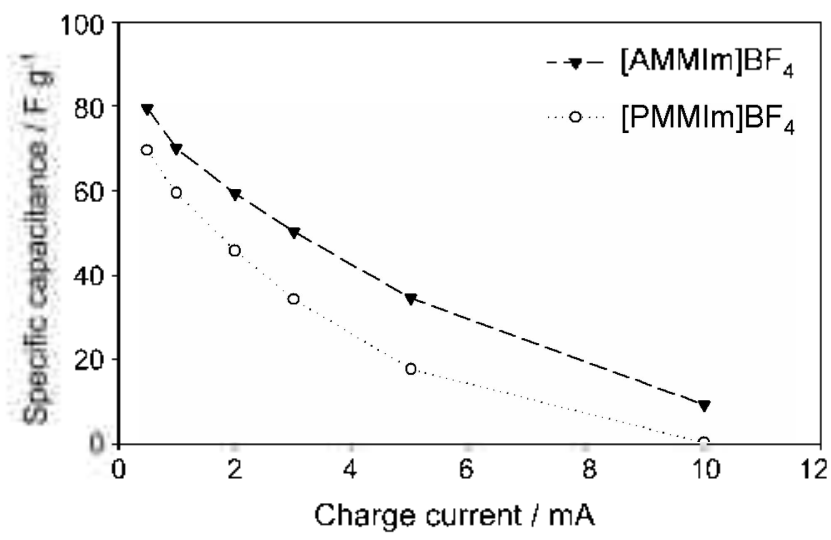

Figure 4. Specific capacitance and current density of an F.IIC. will the II.s prepared.

specific capacitance of the ГDDICs was measured under various charge/discharge current. [AMMIm]BF 4 showed higher specific capacitance compared with [PMMIm] $\mathrm{BF}_{4}$ (rigure 4) probably because of the higher ionic conductivity

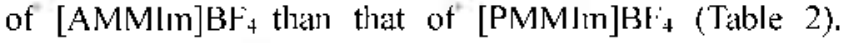
However, [AMMIm] $\mathrm{BF}_{4}$ showed lower capacitance than the reported ionic liquids such as $\left[\mathrm{EM}[\mathrm{m}] \mathrm{H}\left(\mathrm{HF}_{2}\right)_{3}\left(11.1 \mathrm{~F} \mathrm{~cm}{ }^{3}\right)\right.$ and DEME-BF $4\left(25.5 \mathrm{~F} \mathrm{~g}^{\mathrm{l}}\right){ }^{1]}$ The higher conductivity of the IL with an allyl substituent could be explained due to its molecular structure as mentioned above. [AMMLm]B ${ }_{4}$, therefore, could find another application as an electrolyte in electrochemical capacitors in terms of power characteristics.

\section{Conclusions}

Three new 2-methyl substituted imidazolium tetrafluoroborates with an olefinic substituent were synthesized, and their physicochemical properties were compared with those of the II $s$ containing the saturated alkyl substituents. [AMMIm] $\mathrm{Bl}_{4}$ and $\mid \mathrm{CMM} M \mathrm{~B}_{4}$ were liquid at room temperature. All of them were themally less stable than their analogues with saturated alkyl groups but more stable than conventional organic carbonate electrolytes.


and higher ionic conductivity compared with the corresponding Ils containing the saturated alkyl groups. These results could be rationalized by their relatively planar structures. [AMMIm] $\mathrm{BF}_{\downarrow}$ showed a wider electrochemical window on both $\mathrm{Pt}$ and glassy carbon electrodes. [AMMIm] $\mathrm{BJ}_{4}$ exhibited the widest electrochemical window of $7.4 \mathrm{~V}$ on the P1 electrode. Some enhancement could also be observed when a glassy carbon electrode was used. showing an even wider electrochemical window of $9.2 \mathrm{~V}$. In an application to a capacitor as an electrolyte, the EDLC using [AMMIm] $\mathrm{BF}_{4}$ showed higher specific capacitance than that using $[\mathrm{PMMlm}] \mathrm{BF}_{4}$.

Acknowledgement. This work was supported by the Division of Advanced Batteries in NGF: Program (Project No. 10016439) and by KOSГF through the Research Center for Energy Conversion and Storage. We also gratefully acknowledge the financial support by the BK 21 Project funded by the Ministry of Education and Human Resources Development of Korea.

\section{References}

1. (a) Wilton. T. Chem. Rev 1999. 99. 2071-2083. (b) Atthonly. J. L.: Brennecke. J. F.: Holbrev. J. D.: Magintl. E. I.: Mantz. R. A.: Rogers. R. D.: Trulove. P. C.: Visser. A. F.: Welton. T. In Ionic ligutds in Symhesis: Wasserscheid. P.: Welton. T., Eds.: WileyVCII Verlag: Weinheim. 2003; pp 41-126. (c) Song. C. I:.: Yoon. M. Y.: Choi. D. S. Bull. Komew Chem. Soc. 2005. 26. 1321-1330. (d) Jorapur. Y. R.: Chi. D. Y. Bull. Norean Chem. Soc. 2006. 27. 345-354.

2. (a) Wasserscheid. P.: Keim. W. Angew! (hem. hit. Fd 2000. 30. 3772-3789. (b) Dyson. P. J. Transition Wet. (hem. 2002. 27. 353358 .

3. (a) Bonhote. P': Dias. A.-P': Armand. M.: P'apageorgiou. N.: Kalyanasundaram. K.: Gratzel. M. Inorg. Chem. 1996. 35. 11681178. (b) Lec. J. S.: Bac. J. Y.: Lec. H.: Quan. N. D.: Kim. H. S.: Kin. I1. J. hid Eng. (hem. 2004. 10. 1086-1089.

4. (al) Burgeo, M. C.. Fvans, R. (i: Compton. R. (i. ChemP/nsC 'hem 2004, 5. 1106-1120. (b) Hectrochemical Aspets of tonic Liquids: Ohno. H.. ed.: Wiley-Interscience: Hohoken. 2005: pp 173-223. (c) Webber. A.: Blomgren. G E. In Adrences in Lithim-lon Batteries: van Schalkwijk. W. A. Scrosati. B.. Eds.: Kluwer Academic/Plenum Publishers: New York. 2002: pp 185-232.

5. Min. (i-Il.: Yim. I.: Lee. [1. Y.: Jluh. 1). [].: I ee, J:.: Mun. J.: (Oh. S. M.: Kim. Y. (i Butl. Korean ('fem. Soc. 2006. 27. 847852 .

6. Nakagawa. H.: Izuchi. S.: Kuwana. K.: Vukuda. T.: Aihara. Y. J. Electrochem. Soc. 2003. 150. A695-A700.

7. (a) Gifford. P. R.: Palmisano, J. B. J. Flectrochem. Soc. 1987, 1.34. 610-614. (b) Koch. V. R.: Nanjuudiah. C.: Appetecchi. (i B.: Scrosati. B. J. Fletrochem. Soc. 1995. 1+2.1.116-1.118.

8. Wilkes. J. S.: Laworotko. M. I. J. Chem. Soc., Chem. Commun. 1992. $965-967$.

9. Sun. J.: MacFarlane. D. R.: Forsyth. M. Electrochim. Acta 2003. $48,1707-1711$.

10. Lee. J. S.: Quan. V. I.: Ilwang. J. M.: Bale. J. Y.: Kim. H.: Cho. 13. W.: Kim. II. S.: I.e. 11. Hitetrofhem. (ommun. 2006. 8.460 464.

11. (a) Ue. M.: Takeda. M.: Toriumi. A.: Kominato. A.: Hagiwara. R.: Itob. Y. J. Electrochent. Soc. 2003. 150. A499-A502. (b) Sato. T.: Masidat (i: Takagi. K. Electrochm Acta 2014. 40, 3603-3611. 